\title{
Total Mercury in Fish and Benthic Invertebrates Collected from Olt River, Romania
}

\author{
GABRIELA GEANINA VASILE ${ }^{1 \#}$, STEFANIA GHEORGHE ${ }^{1 *}$, CORINA ENE ${ }^{2}$, ECATERINA ANCA SERBAN ${ }^{1,3}$, CATALINA STOICA $^{1 *}$ \\ ${ }^{1}$ National Research and Development Institute for Industrial Ecology - ECOIND, 71-73 Drumul Podul Dambovitei Str., 060652, \\ Bucharest, Romania \\ 2Petroleum-Gas University of Ploiesti, Faculty of Economic Sciences, 39 Bucharest Blvd., 100680, Ploiesti, Romania \\ ${ }^{3}$ University Politehnica of Bucharest, Faculty of Applied Chemistry and Materials Science, 1-7 Polizu Str., 011061, Bucharest, \\ Romania
}

\begin{abstract}
The paper presents an assessment study on the determination of total mercury from biological samples, using Cold-Vapour Atomic Absorption Spectrometrytechnique which was applied on three certified reference materials: Tuna Fish ERM-CE464, Fly ash BCR-176R and Sandy Soil ERM-CC018. Recovery rates ranged from 100 to $108.8 \%$. The method was applied on contaminated biological real samples, respectively various fish organs (Cyprinus carpio and Carrasius gibelio) as well as two types of bivalves (Dreissena sp. and Anodonta sp.) collected from Olt River after the wastew ater discharge of a chemical platform. The preliminary results showed that total $\mathrm{Hg}$ content was above the limit allowed by the World Health Organization $(0.5 \mathrm{mg} / \mathrm{kg})$ in muscle and spleen samples harvested from carp specimens. In benthic invertebrate specimens, the $\mathrm{Hg}$ content ranged from 0.19 to $0.52 \mathrm{mg} / \mathrm{kg}$ dry matter in internal organs, while Hg value in shells was below the method quantification limit.
\end{abstract}

Keywords: mercury, fish, mollusks, contamination, surface water, Olt

In recent years, scientific research sets a warming signal to the world about the risks incidence on the human health arising from metal pollution, as a result of excessive industrialization, freshwater and / or marine water pollution, population and urbanization growth [1-8].

Mercury $(\mathrm{Hg})$ proved to be a very damaging pollutant for the environment, occuring as a result of both anthropogenic and natural activities, respectively [1,9-11]. The main sources of $\mathrm{Hg}$ release in the environment through natural processes are volcanic activity, rock degradation and geothermal activity, while mercury-producing anthropogenic sources consist of metal manufacturing and refining, coal and oil burning, waste incineration, as well as particular industrial processes leading to the discharge of $\mathrm{Hg}$ compounds into wastew ater either in urban sewage or directly into surface water $[9,12,13]$.

Mercury is generally found in the water, air, soil, sediments, plants and animals in the organic forms (methylmercury, dimethylmercury), in the metallic form $\left(\mathrm{Hg}^{0}\right)$ and in the form of ionic mercury salts $\left(\mathrm{HgCl}_{2}, \mathrm{HgS}\right)$. At the aquatic ecosystem level, $\mathrm{Hg}$ is a highly toxic pollutant due to its ability to bio-accumulate $[9,12,14]$. The toxicity of $\mathrm{Hg}$ depends on the chemical form which is taken up by the living organism, the organic forms being the most toxic $[15,16]$. Mercury transformation occurs through biotic and abiotic reduction or oxidation reactions, but also by photolysis of organomercury compounds $[9,12,14]$. The mode of action, time exposure, the $\mathrm{Hg}$ concentrations to which the aquatic organism is exposed and their bioavailibility, the life stage of the organism, as well as the health of the exposed organism, influence the degree of $\mathrm{Hg}$ toxicity on the body. The mechanism by which this metal accumulates in the fish body is achieved by fixing the Hg to the cysteine thiol group, available in proteins [ 9 , 17-19].

The factors that influence the concentration of $\mathrm{Hg}$ accumulated in fish are: age, circumference, weight, fish length and water body characteristics (for example: concentration, $\mathrm{pH}$, reduction-oxidation potential). The accumulated concentration also varies depending on the type of fish, the habitat of the fish origin, the geographical origin and the fishing season [9]. Therefore, predatory fish and larger fish, with a longer lifespan, accumulate a higher concentration of $\mathrm{Hg}$, compared to smaller fish within the same aquatic population. Fish with an increased amount of fat accumulate less $\mathrm{Hg}$, compared to those who have a lower amount of fat $[9,18,19]$.

Various studies have been conducted on the concentration of $\mathrm{Hg}$ that accumulates in different fish organs. In a study performed in 2018 by Q. Xu et al. the fish were analyzed in order to determine the total $\mathrm{Hg}$ and methylmercury concentrations in the following fish organs: gills, heart, liver, muscle and bladder, aiming to highlight the level of toxicity in each of above mentioned organs [18]. The study results showed that the highest total $\mathrm{Hg}$ concentration $(0.5 \mathrm{ng} / \mathrm{g})$ and methylmercury concentration $(0.1 \mathrm{ng} / \mathrm{g})$ were found in the fish muscle, but they were below the maximum allowable limit recommended by the World Health Organization ( $500 \mathrm{ng} / \mathrm{g}$ for total mercury and $300 \mathrm{ng} / \mathrm{g}$ for methylmercury). Moreover, heart, liver, bladder and gills were the organs in which $\mathrm{Hg}$ compounds were accumulated [18]. Thus, a great capacity to accumulate mercury was found for the muscle, compared to other fish organs.

Since $\mathrm{Hg}$ in the fish body accumulates more in muscle tissue than in fat deposits, processing fish contaminated with $\mathrm{Hg}$ does not reduce the $\mathrm{Hg}$ content of the muscle tissue. In the cooking process, the $\mathrm{Hg}$ content present in the fish muscle is not destroyed / eliminated or reduced, due to the connections of $\mathrm{Hg}$ compounds to proteins and free amino acids, which are components of muscle tissues $[9,19]$. As fish and seafood (crustaceans and mollusks) accumulate $\mathrm{Hg}$ from the environment, about $90 \%$ of the total $\mathrm{Hg}$ in fish species is supposed to be methylmercury, while in the case of seafood methylmercury accounts for $60 \%$ of the total mercury concentration $[9,17-19]$. 
The determination of $\mathrm{Hg}$ content in water is essential to ensure the aquatic ecosystems quality [20]. The most commonly used technique for determining $\mathrm{Hg}$ in biological samples is AAS-CV (Cold-Vapour Atomic Absorption Spectrometry), due to the fact that the necessary equipment is more easily accessible to the laboratories that perform the analytical control of the environmental factors. The technique uses several reducing agents with a different reduction power that cause the reduction of inorganic $\mathrm{Hg}$ to elemental $\mathrm{Hg}$ (sodium borohydride, tin chloride) after a preliminary oxidation of organic $\mathrm{Hg}$ compounds to inorganic mercury $[11,19]$.

Before determining the $\mathrm{Hg}$ content by atomic absorption spectrometry, the tissue sample is decomposed through the chemical digestion process. The chemical digestion process can be carried out using an oxidant such as: potassium persulfate, hydrogen peroxide, potassium permanganate, bromine and potassium dichromate with $\mathrm{Cd}^{2+}$ as a catalyst [15]. The chemical digestion process is follow up by a thermal process (microwave, ultrasonic heating bath) [21].

The present study proposes a method of total digestion of mercury from biological samples and applies the method previously verified on three types of CRMs in the preliminary investigation of the $\mathrm{Hg}$ bioaccumulation in aquatic organisms as a result of industrial pollution by the discharge of mercury-containing wastewater into surface water of OltRiver.

\section{Experimental part}

Studied area

The studied area is located in the lower basin of the Olt River, at $12 \mathrm{~km}$ South of Ramnicu Valcea Municipality, in the vicinity of an industrial platform. The sampling points were selected both before and after the industrial platform discharges, as follows: 1) Priza Olt represented the upstream sampling points; 2) Cremenari bridge sampling point was located at a distance of about 8-10 km from the industrial wastewater discharge and about $12 \mathrm{~km}$ from Priza Olt; 3) Babeni Marcea (hydropower) was located downstream of the industrial platform at about $12 \mathrm{~km}$ from the Cremenari bridge; 4) Zavideni village sampling point was located about $30 \mathrm{~km}$ from the Cremenari Bridge and 5) Dragasani sampling point was selected about $45 \mathrm{~km}$ from Cremenari bridge. The sampling points were integrated in R005 and R010 typological category according to The Management Plan of Olt Hydrological Basin [22].

The freshwater samples (surface water and sediment) as well as the aquatic organisms (fish and benthic invertebrates) were collected in November 2018, from sampling points in accordance with the international regulations in force. The biotic and abiotic samples were preserved and transported in freezing containers $\left(4^{\circ} \mathrm{C}\right)$. The total $\mathrm{Hg}$ content was determined by a laboratory certified SR EN ISO 17025 laboratory.

Table 1 centralized the type of samples collected for total mercury content as well as the corresponding sampling points.

\section{Materials and methods}

Water samples were pretreated and $\mathrm{Hg}$ was determined in accordance with international standard ISO 17852: 2006, Water quality -Determination of mercury -Method using atomic fluorescence spectrometry. For sediment, the samples were prepared and the mercury content was determined according to ISO 16772: 2004 standard, Soil quality -Determination of mercury in aqua regia soil extracts with cold-vapour atomic spectrometry or coldvapour atomic fluorescence spectrometry. Applied technique for sediments was CV-AAS, particle size less than $63 \mu \mathrm{m}$ were used for mercury extraction.

Total $\mathrm{Hg}$ content was determined on fish and benthic invertebrate organs after lyophilization, homogenization, acid treatment, and mineralization in the microwave oven, the method being verified using three Certified Reference Materials (CRMs), namely: Tuna Fish ERM-CE464, Fly ash BCR-176R and Sandy Soil ERM-CC018.

The gills, skin, muscles, liver, kidney, intestine, spleen, gonad, brain samples were lyophilized for a period of 40 hours at $-54^{\circ} \mathrm{C}$ and then grinded in a mortar (where the amount of sample allowed this), weighed and mineralized in the microwave oven to determine the total mercury content.

Similar treatment was applied for bivalves (Dreissena and Anodonta sp.), except for the shells, who were lyophilized for $48 \mathrm{~h}$ at $-54^{\circ} \mathrm{C}$ and then processed for $\mathrm{Hg}$ detection. In case of benthic invertebrates, the $\mathrm{Hg}$ content was detected from bivalves organism body (including all internal organs) and the shells. The total biomass of the bivalves was quantified using AG135 analytical balance (Mettler Toledo, USA).

The maximum amount of lyophilized tissue was at least $0.5 \mathrm{~g}$. A mixture of $9 \mathrm{~mL}$ of $\mathrm{HNO}_{3}$ and $1 \mathrm{~mL}$ of $\mathrm{H}_{2} \mathrm{O}_{2}$ was used. In case of high organic matter (fats) in the biological samples, $2 \mathrm{~mL}$ of hydrogen peroxide was added.

During the experiment, several microwave oven digestion programs were tested to detect the total mercury content of fish. Table 2 presented the method for which the best extraction percentages were obtained.

After digestion, the samples were filtered and filled up to $50 \mathrm{~mL}$ volumetric flask with ultrapure water. Determination of total $\mathrm{Hg}$ content in biological samples was performed using the Cold-Vapour Atomic Absorption

\begin{tabular}{|c|c|c|c|c|c|c|}
\hline No. & Sampling point & Type of sample & No. & Sampling point & Type of sample & \multirow{4}{*}{$\begin{array}{c}\text { Table } 1 \\
\text { TYPES OF SAMPLES } \\
\text { COLLECTED FROM } \\
\text { LOWER BASIN OF OLT } \\
\text { RIVER }\end{array}$} \\
\hline 1. & Priza Olt & $\begin{array}{l}\text { Surface water } \\
\text { Sediment }\end{array}$ & 4. & Zavideni & $\begin{array}{l}\text { Surface water } \\
\text { Sediment } \\
\text { Benthic Invertebrates } \\
\text { (Dreissena sp.) }\end{array}$ & \\
\hline 2. & Cremenari & $\begin{array}{l}\text { Surface water } \\
\text { Sediment }\end{array}$ & & & Surface water & \\
\hline 3. & Babeni-Marcea & $\begin{array}{l}\text { Surface water } \\
\text { Sediment } \\
\text { Fish(Carassius } \\
\text { gibelio, Cyprimusc arpio) }\end{array}$ & 5. & Cremenari & $\begin{array}{l}\text { Sediment } \\
\text { Benthic Invertebrates } \\
\text { (Anodonta sp.) }\end{array}$ & \\
\hline
\end{tabular}

\begin{tabular}{|l|l|}
\hline Step 1 & 15 minutes, $1400 \mathrm{~W}$, temperature ramp up to $120^{\circ} \mathrm{C}$ \\
\hline Step 2 & 15 minutes, $1400 \mathrm{~W}$, maintaining the temperature at $120^{\circ} \mathrm{C}$ \\
\hline Step 3 & Cooling, 10 minutes \\
\hline
\end{tabular}

Tabble 2

DIGESTION PROGRAM ONETHOS UP MILESTONE MICROWAVE DIGESTION SYSTEM 


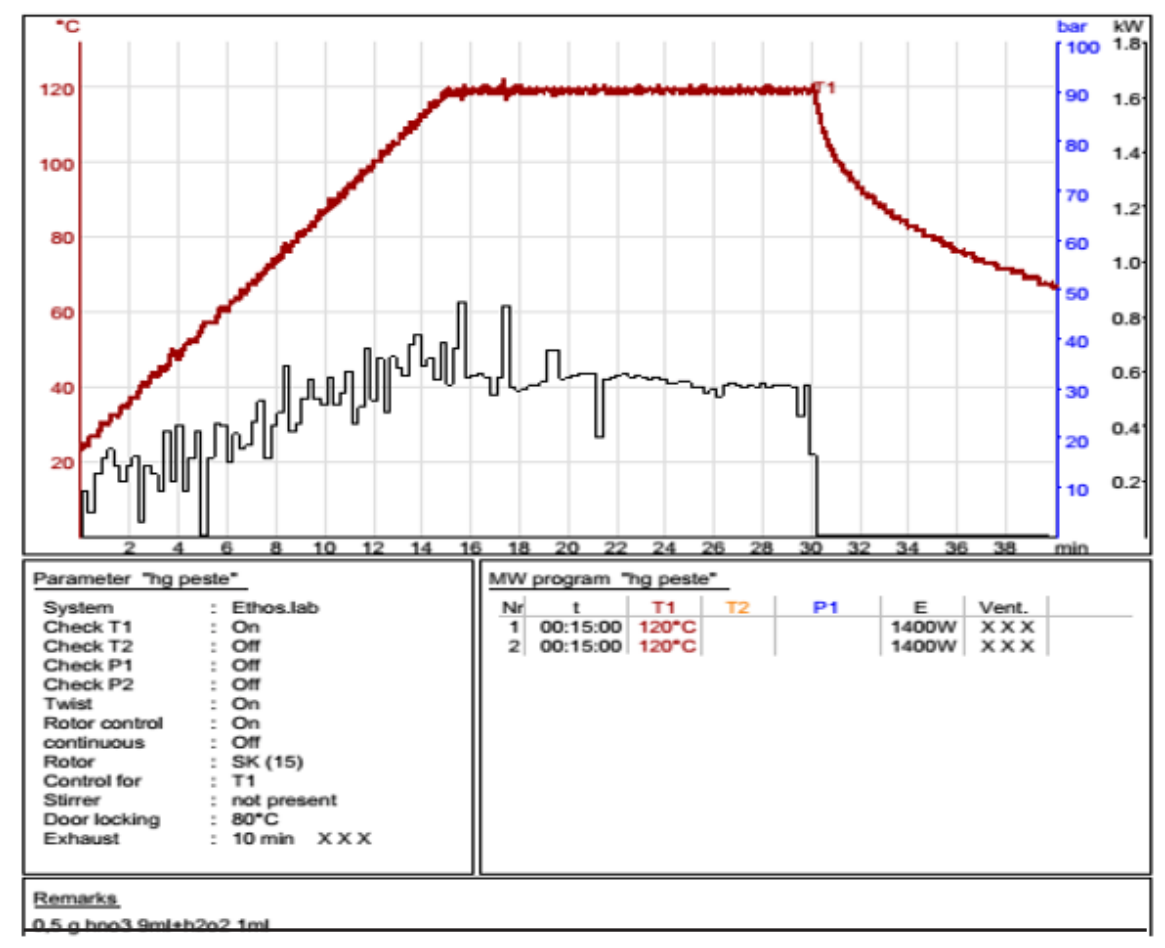

Spectrometry technique, adapting the applied method for solid samples to the biological matrix. The calibration curve was performedusing Certified Reference Material $\mathrm{Hg} 1000$ $\mathrm{mg} / \mathrm{L}$ and was set in the range 1 to $10 \mu \mathrm{g} / \mathrm{L}$. Inorganic $\mathrm{Hg}$ was transformed to $\mathrm{Hg}^{0}$ after a reaction with $10 \% \mathrm{SnCl}_{2}$ solution, mercury vapor being detected using a $\mathrm{Hg}$ hallow cathode lamp of the AAS equipment.

The diagram on the temperature and pressure control console for the digestion program applied to the microwave system was presented in figure 1 .

\section{Results and discussions}

$\mathrm{Hg}$ total content in CRMs

Table 3 showed the results for total mercury content in three types of matrices including fish tissue and $\mathrm{Hg}$ standard samples compared to the certified values. The recovery percentages were representing as the mean of two determinations per separate sample.
Fig. 1. Temperature control in the digestion program applied for total $\mathrm{Hg}$ determination
The certified values according to J oint Research Center, Institute for Reference Materials and Measurements in the case of Tuna Fish CRM for the methyl mercury content was at $5.50 \pm 0.17 \mathrm{mg} / \mathrm{kg}$. In this particular case, the recovery rate was $103.6 \%$, a more realistic value given that the value of total $\mathrm{Hg}$ was lower than that of methylmercury in Tuna Fish.

\section{$\mathrm{Hg}$ content in surface water and sediment samples}

The monitoring data regarding the surface water and sediment quality collected from Olt River, data obtained by the researchers from the National Research and Development Institute for Industrial Ecology, Ramnicu Valcea Branch (tables 4, 5), indicated that both the surface water and sediment, respectively were contaminated with $\mathrm{Hg}[23,24]$.

Table 3

TOTAL MERCURY CONTENT AND RECOVERY RANGES FOR USED CRMS

\begin{tabular}{|c|c|c|c|c|c|c|}
\hline $\begin{array}{l}\text { Total } \mathrm{Hg} \\
\text { concentration }\end{array}$ & M.U. & $\begin{array}{c}\text { Tuna fish } \\
\text { ERM-CE464 }\end{array}$ & $\begin{array}{c}\text { Fly ash } \\
\text { BCR-176R }\end{array}$ & $\begin{array}{c}\text { Sandy Soil ERM- } \\
\text { CC018 }\end{array}$ & \multicolumn{2}{|c|}{$\begin{array}{c}\text { CRM Hg } \\
(\mu \mathrm{g} / \mathrm{L})\end{array}$} \\
\hline Certified Value & $\mathrm{mg} / \mathrm{kg}$ & $5.24 \pm 0.10$ & $1.60 \pm 0.23$ & $1.38 \pm 0.06$ & 10.0 & 4.00 \\
\hline $\begin{array}{l}\text { Detected } \\
\text { value }\end{array}$ & $\mathrm{mg} / \mathrm{kg}$ & $5.70 \pm 0.57$ & $1.60 \pm 0.16$ & $1.41 \pm 0.14$ & 9.85 & 4.25 \\
\hline $\begin{array}{l}\text { Recovery } \\
\text { percentage }\end{array}$ & $\%$ & 108.8 & 100 & 102.2 & 98.5 & 106.3 \\
\hline
\end{tabular}

Table 4

MERCURY CONTENT IN SURFACE WATER COLLECTED FROM OLT RIVER ( $\mu \mathrm{G} / \mathrm{L}$ )

\begin{tabular}{|c|c|c|c|c|c|}
\hline Location & Period & $\mathrm{Hg}$ & Location & Period & $\mathrm{Hg}$ \\
\hline \multirow[t]{6}{*}{ PrizaOlt } & July 2014 & 4.8 & \multirow[t]{6}{*}{ Cremenari } & July 2014 & 6 \\
\hline & August 2014 & 23 & & August 2014 & 4.2 \\
\hline & September 2014 & 44 & & September 2014 & 46 \\
\hline & October 2015 & 39 & & October 2015 & 72 \\
\hline & February 2016 & $<0.2$ & & February 2016 & $<0.2$ \\
\hline & November 2018 & $<0.2$ & & November 2018 & $<0.2$ \\
\hline \multirow[t]{6}{*}{ Babeni - Marcea } & July 2014 & 5 & Zavideni & November 2018 & $<0.2$ \\
\hline & August 2014 & 2.6 & Dragasani & November 2018 & $<0.2$ \\
\hline & September 2014 & 47 & & & \\
\hline & October 2015 & 36 & & & \\
\hline & February 2016 & $<0.2$ & & & \\
\hline & November 2018 & $<0.2$ & & & \\
\hline EQSD allowed va & & 0.07 & & & \\
\hline
\end{tabular}

Note: Values in red indicate exceeding of maximum permissible value [25]. 
Thus, during the 2014-2015 monitoring period, the water quality framed the Olt River in polluted freshwater aquatic environment. The $\mathrm{Hg}$ content was even 100 times higher than the allowed value of $0.07 \mu \mathrm{g} / \mathrm{L} \mathrm{[25] \text {. }}$

In this study, the total $\mathrm{Hg}$ content detected in November 2018 in surface water samples was below $0.2 \mu \mathrm{g} / \mathrm{L}$ in all of the above mentioned five sampling points. The total $\mathrm{Hg}$ content detected in the sediment samples was below the $\mathrm{Hg}$ values recorded during the monitoring period of 20112015 (table 5), [23, 24].

\section{Total Hg in fish}

In order to detect the level of $\mathrm{Hg}$ contamination of the aquatic organisms in close proximity of Priza Olt Cremenari - Babeni Marcea, in November 2018 two species of native fish (Carassius gibelio and Cyprinus carpio) were collected from the Olt River using traditional method.

The maximum allowed limit for $\mathrm{Hg}$ in fishery products is $0.5 \mathrm{mg} / \mathrm{kg}$ according to Regulation (EC) No. Commission Regulation (EC) No 1881/2006 of 19 December 2006 laying down maximum levels for certain contaminants in foodstuffs, with the indication that if the fish are intended to be consumed in their entirety, the maximum level applies to the whole fish.

Preliminary results revealed exceedances of total mercury concentrations in white and red muscles of the Prussian carp, as well as in the spleen (table 6). The concentrations detected in gills, skin, liver, kidney, intestine, brain and intestine samples were below the admissible limit of $0.5 \mathrm{mg} / \mathrm{kg}$ (table 6). The smaller Prussian carp specimen $(57 \mathrm{~g})$ recorded lower $\mathrm{Hg}$ concentrations compared to the one of $130 \mathrm{~g}$, which may indicate that $\mathrm{Hg}$ bioaccumulation undergoes more in mature fish compared to those in early stages of life. In another study carried out on 13 different fish species, $\mathrm{Hg}$ concentrations ranging between 0.004 and $0.122 \mu \mathrm{g} / \mathrm{g}$ wet weight were detected in muscle tissue [26]. The fish species recorded $\mathrm{Hg}$ concentrations lower than the limit imposed by the World Health Organization, namely $0.5 \mu \mathrm{g} / \mathrm{g}$ wet weight [26]. Similar $\mathrm{Hg}$ values in fish species were presented in other aquatic ecosystems [27, 28].

As for the European carp tissues, no exceedance of the limit for $\mathrm{Hg}$ concentration was observed.

Additional $\mathrm{Hg}$ monitoring studies are needed for both fish species (but also on other species) in order to create a critical assessment of the bioaccumulation effects in aquatic ecosystems with direct implications for human health.

\section{Total $\mathrm{Hg}$ in benthic invertebrates}

The analysis of benthic invertebrates in the samples collected from Priza Olt, Cremenari Bridge and BabeniMarcea Accumulation Lake showed the presence of Oligochaetes species. The biomass of oligochaetes per sample ( $\mathrm{g} / \mathrm{sqm})$ was inadequate for a conclusive analysis of the $\mathrm{Hg}$ content (less than $0.5 \mathrm{~g}$ ).

Table 5

MERCURY CONTENT IN SEDIMENT SAMPLES COLLECTED FORM OLT RIVER ( $\mathrm{mg} / \mathrm{kg} \mathrm{dm}$.)

\begin{tabular}{|c|c|c|c|c|c|}
\hline Location & Period & $\mathrm{Hg}$ & Location & Period & $\mathrm{Hg}$ \\
\hline \multirow[t]{10}{*}{ Priza Olt } & May 2011 & 3.14 & \multirow[t]{10}{*}{ Babeni-Marcea } & May 2011 & 0.78 \\
\hline & August 2011 & $<0.05^{*}$ & & August 2011 & $<0.05^{*}$ \\
\hline & March 2012 & $<0.05^{*}$ & & March 2012 & $<0.05 *$ \\
\hline & August 2012 & 0.08 & & August 2012 & $<0.05^{*}$ \\
\hline & October 2012 & 0.06 & & October 2012 & $<0.05^{*}$ \\
\hline & June 2013 & 0.72 & & June 2013 & 0.39 \\
\hline & May 2014 & 1.77 & & May 2014 & $<0.05 *$ \\
\hline & February 2015 & 0.98 & & February 2015 & 0.74 \\
\hline & April 2015 & 0.49 & & April 2015 & 0.30 \\
\hline & November 2018 & 0.12 & & November 2018 & 0.11 \\
\hline \multirow[t]{12}{*}{ Cremenari } & May 2011 & 0.76 & \multirow[t]{3}{*}{ Zavideni } & February 2015 & 0.85 \\
\hline & August 2011 & $<0.05^{*}$ & & April 2015 & 0.09 \\
\hline & March 2012 & $<0.05^{*}$ & & November 2018 & 0.05 \\
\hline & August 2012 & 0.14 & \multirow[t]{3}{*}{ Dragasani } & February 2015 & 0.80 \\
\hline & October 2012 & $<0.05^{*}$ & & April 2015 & 0.11 \\
\hline & June 2013 & 0.66 & & November 2018 & $<0.05 *$ \\
\hline & May 2014 & 0.62 & & & \\
\hline & February 2015 & 1.04 & & & \\
\hline & April 2015 & 0.74 & & & \\
\hline & February 2015 & 1.04 & & & \\
\hline & April 2015 & 0.74 & & & \\
\hline & November 2018 & 0.10 & & & \\
\hline
\end{tabular}

Table 6

TOTAL Hg CONTENT IN SAMPLES OF FISH COLLECTED IN OLT RIVER (BABENI MARCEA ACCUMULATION LAKE) AT APPROX. 8 Km AFTER OLTCHIM EVACUATION, TRADITIONAL FISHING

\begin{tabular}{|c|c|c|c|c|c|c|c|c|c|c|}
\hline Organ & $\begin{array}{l}\text { White } \\
\text { muscle }\end{array}$ & $\begin{array}{c}\text { Red } \\
\text { muscle }\end{array}$ & Gill & Skin & Liver & Kidney & Spleen & Brain & Gonads & Intestine \\
\hline \multicolumn{11}{|c|}{ Species, concentration (mg/kgd.m. $=\mu g / g d . m)}$. \\
\hline $\begin{array}{l}\text { Prussian } \\
\text { carp 1* }\end{array}$ & 1.54 & 0.86 & 0.14 & 0.16 & $<0.02$ & \multirow[t]{2}{*}{0.25} & \multirow[t]{2}{*}{1.34} & \multirow[t]{2}{*}{0.07} & - & 0.40 \\
\hline $\begin{array}{l}\text { Prussian } \\
\text { carp } 2^{* *}\end{array}$ & 0.87 & 0.48 & 0.04 & 0.13 & $<0.02$ & & & & 0.03 & 0.16 \\
\hline $\begin{array}{l}\text { European } \\
\text { carp } 1^{* * * *}\end{array}$ & 0.02 & 0.04 & 0.18 & 0.21 & 0.19 & - & - & - & - & 0.20 \\
\hline
\end{tabular}

${ }^{8}$ Carassius gibelio (Prussian carp 1), W=130g, $\mathrm{Tl}=19 \mathrm{~cm}, \mathrm{Sl}=15 \mathrm{~cm} ;$

${ }^{8 *}$ Carassius gibelio (Prussian carp 2), W $=5.2 \mathrm{~g}, \mathrm{Tl}=15.5 \mathrm{~cm}, \mathrm{Sl}=13 \mathrm{~cm}$;

$* *$ (Cyprinus carpio (European carp 1), W=52g, Tl= $14 \mathrm{~cm}, \mathrm{Sl}=11,5 \mathrm{~cm}$

$\mathrm{W}=$ weight $/$ specimen; $\mathrm{Tl}=$ total length (including tail); $\mathrm{Ls}=$ standard length (without tail) 
Tabble 7

TOTAL Hg CONCENTRATION IN BIVALVES ORGANISMS BODY AND EXTERNAL SHELL $(\mathrm{mg} / \mathrm{kg}$ )

\begin{tabular}{|c|c|c|c|c|c|c|c|}
\hline \multirow{2}{*}{ Location } & \multicolumn{3}{|c|}{ Dreissena sp. } & \multirow{2}{*}{$\begin{array}{c}\text { Anodonta } \\
\text { sp. }\end{array}$} & \multirow{2}{*}{$\begin{array}{c}\text { External } \\
\text { shell } \\
\text { Sample } 1\end{array}$} & \multirow{2}{*}{$\begin{array}{l}\text { External } \\
\text { shell } \\
\text { Sample } 2\end{array}$} & \multirow{2}{*}{$\begin{array}{c}\text { External shell } \\
\text { Sample } 3\end{array}$} \\
\hline & Sample1 & Sample2 & Sample3 & & & & \\
\hline Zavideni & - & - & - & 0.19 & $<0.02$ & $=0.02$ & $<0.02$ \\
\hline Dragasani & 0.20 & 0.35 & 0.52 & - & $=0.02$ & $=0.02$ & $<0.02$ \\
\hline
\end{tabular}

Instead, several specimens of Dreissena sp. were identified in the sediment collected from Zavideni. The total biomass of Dreissena sp. w of $26 \mathrm{~g} / \mathrm{sqm}$. In addition, the benthic invertebrates analysis showed the presence of Anodonta sp. at Dragasani sampling point. The total biomass of Anodonta sp. species was of $45 \mathrm{~g} / \mathrm{sqm}$. $\mathrm{Hg}$ concentrations was detected for the bivalves internal organs. The $\mathrm{Hg}$ content detected from the shells of both Dreissena sp. and Anodonta sp., respectively was lower than quantification limit (Table 7). Similar results for the bioaccumulation of various heavy metals in benthic invertebrates and other aquatic organisms were presented in other research studies [29-32]. The results recorded in bivalves species (internal organs) showed total $\mathrm{Hg}$ concentrations ranging from $0.19 \pm 0.52 \mathrm{mg} / \mathrm{kg}$. In all external shell samples, both for Dreissena sp. and Anodonta $s p$., the $\mathrm{Hg}$ content was below the quantification limit of the applied method (Table 7).

\section{Conclusions}

The Cold-Vapour Atomic Absorption Spectrometry technique applied for determination of total $\mathrm{Hg}$ in biological samples resulted in recovery percentages ranging between 100 and $108.8 \%$. Those recovery percentages allowed its application in preliminary studies regarding total $\mathrm{Hg}$ bioaccumulation in aquatic organisms.

Furthermore, preliminary investigations of $\mathrm{Hg}$ concentration of water quality in Olt River revealed a possible $\mathrm{Hg}$ contamination, consisting of its accumulation in time in the sediment and subsequently in aquatic organisms. Thus, different amounts of total $\mathrm{Hg}$ were determined both in fish species (Prussian carp and European carp) and bivalves, respectively. In some fish organs (muscle and spleen), the determined total $\mathrm{Hg}$ concentration was above the WHO's maximum allowed value. Even if at the time of the study, both in surface water and sediment, the $\mathrm{Hg}$ content was within the admissible limits, according to the data published during 2011-2015 period, the historical pollution of the freshwater system led to bioaccumulation in benthic invertebrates (bivalves) as well as in vertebrates (fish).

Future studies will focus through spatial-temporal investigations in situ on a larger number of specimens, and also on wider diversity of aquatic species.

Acknowledgements. The authors acknowledge the financial support offered by The National Research Program Nucleu through Agreement no. 38N/2018, Project code PN 18050101.

\section{References}

1. STOICA, C., CAMEJ O, J., BANCIU, A., NITA-LAZAR, M. , PAUN, I. , CRISTOFOR, S., ROCHA PACHECO, O., GUEVARA LOPEZ, M., Water Sci.Technol.,73, no. 10, 2016, p. 2413.

2. KIM, L., VASILE, G.G., STANESCU, B., DINU, C., ENE, C., Rev.

Chim.(Bucharest), 67, no.8, 2016, p.1441.

3. DINU, C., UNGUREANU, E.M., VASILE, G.G, KIM, L., IONESCU, I., ENE, C., SIMION, M., Rev. Chim. (Bucharest), 69, no.1, 2018, p.14.
4. VASILE, G., KIM, L., GHEORGHE, ST., STANESCU, B., 13th International Multidisciplinary Scientific Geoconference, Ecology, Economics, Education and Legislation, SGEM Conference Proceedings, Ecology and Environmental Protection, 1, 2013, p. 299.

5. KIM, L., VASILE, G.G., STANESCU, B., CALINESCU, S., BATRANESCU Ghe., J. Environ. Prot. Ecol., 16, no.4, 2015, p.1307.

6. DINU, C., UNGUREANU, E.M., VASILE, G.G., KIM, L., PASCU, L.F., SIMION, M., Rev. Chim. (Bucharest), 69, no.11, 2018, p.4141.

7. PETRESCU, M., BUCUR, E., DIODIU, R., BRATU, M., SERBANESCU, A., BARBU, M., $20^{\text {th }}$ International Symposium „The Environment and the Industry", Proceedings Book, 2017, p.213.

8. BUCUR, E., IONITA, L., PETRESCU, M., J. Environ. Prot. Ecol., 11, no.3, 2010, p.809.

9. COSTA, L.G., FATTORI, V., J oint FAO/WHO Expert consultation on the risks and benefits of fish consumption, health risks associated with fish consumption focus on methylmercury, dioxins and dioxinlike PCBs, 2010.

10. *** EFSA Journal, 12, no. 7, 3761, 2014, p. 1, doi:10.2903/ j.efsa.2014.3761.

11. RIO SEGADE, S., TYSON, J.F., Spectrochim. Acta PartB At. Spectrosc., 54, 2003, p. 1031.

12. FERREIRA, S.L.C., LEMOS, V.A., SILVA, L.O.B., QUEIROZ, A.F.S., SOUZA, A.S., DA SILVA, E.G.P., DOS SANTOS, W.N.L., DAS VIRGENS, C.F., Microchem. J., 121, 2015, p. 227.

13. SAHUQUILLO, I., LAGARDA, M.J. ., SILVESTRE, M.D., FARRE ROVIRA, R., Food Addit. Contam., 24, no 8, 2007, p. 869, doi: 10.1080/ 02652030701258760.

14. CORNELIS, R., CARUSO, J.A., CREWS, H., HEUMANN, K.G., Eds. Handbook of Elemental Speciation II: Species in the Environment, Food, Medicine and Occupational Health, John Wiley \& Sons, Chichester, England, 2005.

15. CORDEIRO, F., GONCALVES, S., CALDERÓON, J., ROBOUCH, P., EMTEBORG, H., CONNEELY, P., TUMBA-TSHILUMBA, M-F., KORTSEN, B., DE LA CALLE B., IMEP-115, European Commission, 2013. 16. *** The EFSA J ournal, no. 34, 2004, p. 1, EFSA-Q-2003-030.

17. SADHU, A.K., KIM, J.P., FURRELL, H., BOSTOCK, B., Mar. Pollut. Bull., 2015, doi.org/10.1016/j.marpolbul.2015.10.013.

18. XU, Q., ZHAOB, L., WANG, Y., XIEA, Q., YINA, D., FENGB, X., WANG, D., Environ. Pollut., 243, part A, 2018, p. 115, doi: 10.1016/ j.envpol.2018.08.048.

19. YAVUZ, E., TOKALIOĐLU, S., PATAT, S., Microchem. J., 142, 2018, p. 85.

20. ZHANGA, Y., MIRÓB, M., KOLEV, S.D., Talanta, 189, 2018, p. 220. 21. VOEGBORLO, R.B., AKAGI, H, Food Chem., 100, no. 2, 2007, p. 853.

22. *** Management Plan of Olt Hydrological Basin, National Administration of Romanian Surface Water, www.rowater.ro/daolt/ SCAR/Planul\%20 de\%20management.aspx, in Romanian.

23. IORDACHE, M., MEGHEA, A., NEAMTU, S., POPESCU, L. R., IORDACHE, I., Rev. Chim. (Bucharest), 65, no. 1, 2014, p. 84.

24. POPESCU, L. R., IORDACHE, M., BUICA, G. O., UNGUREANU, E. M., PASCU, L. F., LEHR, C., Rev. Chim. (Bucharest), 66, no. 12, 2015, p. 2060.

$25 . * * *$ DIRECTIVE 2013/39/UE regarding for priority substances in the field of water policy, www: eur-lex.europa.eu/LexUriServ/ LexUriServ.do?uri=0) :L:2013:226:0001:0017

26. VOEGBORLO, R.B., AKAGI, H., Food Chem., 100, 2007, p. 853-858. 
27. SOARES, J. M., GOMES, J. M., ANJ OS, M.R., SILVEIRA, J. N., CUSTÓDIO, F. B., GLORIA, M. B. A., Food Res. Int., 109, 2018, p. 537543.

28. BASTOS W. R., DOREA, J. G., BERNARDI, J . V. E., LAUTHARTTE, L. C., MUSSY, M. H., LACERDA, L. D., \& MALM, O., Environ. Res., 140, 2015, p. 191-197.

29. STOICA C., GHEORGHE S., LUCACIU I., STANESCU E., PAUN I., NICULESCU D., Soil Sediment Contam., 23, 2014, p. 763.
30. STOICA C., GHEORGHE S., PETRE J., LUCACIU I., NITA-LAZAR M., Environ. Eng. Manag. Journal, 13, no. 9, 2014, p. 2243.

31. GHEORGHE, S., STOICA, C., VASILE, G.G., NITA-LAZAR, M., STANESCU, E., LUCACIU, I.E., Water Quality, InTech, Ed. Hlanganani Tutu, 2017, p. 59-89.

32. GHEORGHE, S., VASILE, G.G., GLIGOR, C., LUCACIU, I.E., NITALAZAR, M., Rev. Chim.(Bucharest), 68, no. 8, 2017, p. 1711.

Manuscript received: 12.08 .2018 